\title{
Healthcare Providers' Perceptions towards Health Information Applications at King Abdul-Aziz Medical City, Saudi Arabia
}

\author{
Abeer Al-Harbi \\ Health \& Hospital Administration department, College of Business Administration \\ King Saud University (KSU) \\ Riyadh, Saudi Arabia
}

\begin{abstract}
-
The purpose of this study was to assess the perceptions of healthcare providers towards health information technology applications in King Abdul-Aziz Medical City in terms of benefits, barriers, and motivations.

The study population consists of all healthcare providers working at KAMC. A sample size of 623 was drawn from a population of 7493 healthcare providers using convenience random sampling method. 377 were returned, giving a response rate of $60.5 \%$.

A self-administered questionnaire was developed based on extended literature review and comprised 25 statements on a fivepoint Likert-scale.

Results indicate that the majority of healthcare providers use KAMC health information applications. The majority of healthcare providers perceived that the applications are valuable and beneficial. However, healthcare providers were split over the barriers to HIT use in KAMC. As for drivers, healthcare providers generally would be motivated to use the IT applications by provision of new applications and training, contribution in change hospital's work procedures, and provision of technical support. Also, there were many barriers identified by healthcare providers. These were insufficient number of computers, frequent system down, and the use of computerized systems is time consuming. Finally, there were significant differences in the perceptions with respect to gender, occupation, and training.
\end{abstract}

Keywords- Healthcare providers; Health Information Technology; Computerized Patient Record; King Abdul-Aziz Medical City.

\section{INTRODUCTION}

\section{a. Health Information Technology (HIT):}

Healthcare information technology (HIT) has become a key preoccupation of healthcare systems worldwide [1, 2]. A review of the literature reveals that there is significant consensus that the implementation of electronic health records (EHRs) and HIT systems is considered among the highest priorities of modern healthcare systems [3].

Clinical practices rely heavily on the collection and analysis of medical data for decision-making abilities when caring for patients [4]. Thus, health information systems are capable of having a significant, positive impact on patient care within healthcare settings [5].
Health information technology is in general increasingly viewed as the most promising tool for improving the overall quality, safety and efficiency of the health delivery system [6,7, 8]. The institute of Medicine (IOM) identified information technology as one the critical forces that could significantly improve healthcare quality and safety [9].

One of the most challenging areas of health information technology is integrating it into the workflow of the healthcare providers [10]. Despite the increasing availability of health information technology applications, anecdotal evidence suggests that its use has not been well accepted by healthcare providers [11,12]. Acceptance of information technologies has occupied a central role in information technology research. There have been many studies investigating IT acceptance in different settings at both individual and organizational levels of analysis and different theoretical models have been used $[13,14]$. The literature provides evidence of failed clinical system implementations, due to lack of adoption by users [15]. However, with few significant exceptions, information system research is scarce regarding information technology acceptance in a healthcare environment $[16,17,18,19]$.

In Saudi Arabia, the government strives to improve quality and safety of healthcare services through adoption health information technology [20]. However, most Saudi health organizations have no electronic health records (HER) systems implemented in their facilities, and they are totally dependent either on manual paper work or on very basic software tools to do their day to day tasks such as patient admissions [21]. KAMC is one of the few hospitals that have a basic EHR system which was later replaced by a computerized Patient Record (CPR) system. CPR is a single integrated system with a comprehensive suite of modules that provides depth and breadth of patient-care support and workflow management. CPR system streamlines administrative functions and eliminates paperwork to get caregivers back in the business of quality patient care. CPR system provides for an array of technological imperatives, including Computerized Physician Order Entry (CPOE), Clinical Decision Support (CDS), automated nursing documentation, integrated pharmacy and automated medication administration. A CPOE system, for example, makes prescription orders legible, identifies the correct medication and dose as well as signals alerts for 
potential medication interactions or allergic reactions [20]. According to Dr. David Brailer, cited in Harrison and Daly [22], CPOE reduces medication errors by 20 percent .

Despite the importance of HIT in improving healthcare efficiency, there were few studies carried on use, barriers and drivers to HIT in Saudi health organizations. Therefore, there is a need for investigating the perceptions of healthcare providers towards the health information technology applications. This research is an attempt to understand the perceptions of healthcare providers towards health information technology applications in King Abdul-Aziz Medical City in terms of benefits, barriers, and motivation toward the use of health information applications. In addition, the research will investigate the effect of demographic and organizational variables on the perceptions of the healthcare providers towards the health information technology applications.

\section{b. King Abdul-Aziz Medical City (KAMC):}

King Abdul-Aziz Medical City commenced its operations in 1983 in Riyadh under National Guard Health Affairs (NGHA). NGHA has passed the requirements for accreditation under the (JCI) Joint Commission International standards with excellent performance in December 2009. The total bed capacity of the hospital is 847 beds. The average length of stay is 4.6 days, and the average number of outpatient visits per day is 3,145 patients. Total number of physicians is 1564 , total number of nurses is 3921, and the total number of clinical/paramedical staff is 2008.

\section{METHODS}

\section{a. Survey Instrument:}

In this study, quantitative research method approach was used. To collect the data, a questionnaire form was designed to achieve the research objectives. Based on extended literature review, appropriate research constructs which had been validated in prior studies were developed. These include benefits, barriers, and motivation to use health information systems. In addition, the questionnaire included a section of general information about the respondents' demographics and organizational variables which were considered as moderators to the perceptions towards the health information applications. The second section included 25 statements regarding the benefits, barriers, and motivation of the health information applications using five-point Likert-scale (1=Strongly Disagree, 2=Disagree, 3=Neither agree nor disagree, 4=Agree, $5=$ Strongly agree). Thereafter, the questionnaire was validated through evaluation by two faculty members of King Saud University, and a pilot study. Cronbach's alpha values for the three dimensions (benefits, barriers, and drivers) were strictly above 0.74 ; meeting the recommended alpha threshold values of at least 0.7 [23;24]. Therefore, all the three dimensions were internally consistent.

\section{b. Population and Sample}

The study population consists of all healthcare providers working at KAMC. The healthcare providers include physicians, nurses, and clinical/paramedical personnel. The population size is 7493. A sample size of 623 was drawn from the population using convenience random sampling method. Convenience sampling is a non-probability sampling technique where subjects are selected because of their convenient accessibility and accessibility to the researcher [25]. The questionnaires with cover letters that explained the purpose of the study were distributed during April/May 2011. Of 623 questionnaires distributed, 377 questionnaires were returned, giving a response rate of 60.5 percent.

\section{c. Analysis:}

Descriptive statistics were used to analyze the demographic and organization variables and the respondents' perceptions towards benefits, barriers, and motivation to use health information systems. One-sample t-test was conducted to determine whether the mean score of each item of the three dimensions (benefits, barriers, motives) is significantly higher than a score 3; this being the mid-point on the Likert scale for "Neither agree nor disagree" response to the item. Two-sample t-test was used to test whether there are differences in respondents' perceptions towards IT benefits, barriers to using IT, and motives to using IT variables with respect to gender. One-way analysis of variance (ANOVA) was used to test whether there are difference in respondents' perceptions towards IT benefits, barriers to using IT, and motives to using IT variables with respect to education and occupation.

\section{RESULTS:}

\section{a. Respondents' Characteristics:}

Table I shows the profile of respondents by age, gender, education, work experience, and occupation. The average respondent's age was 36.2 years associated with a relatively high standard deviation of 9.6 years. This shows the medical workforce at KAMC is young. With respect to gender, the vast majority of the respondents were female, 86.2 percent, while the remaining 13.8 percent were males. The sex disproportion is due to the fact that most of the sample were nurses, 55.2 percent; as nurses are usually females.

In terms of educational background, most of the respondents, 79.3 percent, hold bachelor's degree, followed by 17.2 percent who had postgraduate degree and 3.4 percent had high school education or less.

The work experience of the respondents ranged from one year to twenty-six years. About 43 percent of the respondents had less than five years of work experience; followed by 27.3 percent who had between five to nine years, 20.2 percent between ten to fourteen years, 5.6 percent between fifteen to nineteen years, and lastly 4.2 per cent had work experience of more than twenty years. The average working experience was 7.1 years with a relatively high standard deviation of 5.5 years.

As for occupation, the table shows that about two thirds of the sample were nurses, followed by 17.2 percent were physicians and the same percentage were other medical staff. The results show that the nurse-physician ratio is relatively high; 3.8 nurses per physicians in the sample compared to 2.5 for the Ministry of Health [26].

TABLE I. PROFILE OF RESPONDENTS

\begin{tabular}{|c|c|c|}
\hline Variables & Frequency & Percent \\
\hline Age (Years): & & \\
\hline
\end{tabular}




\begin{tabular}{|c|c|c|}
\hline Variables & Frequency & Percent \\
\hline $20-29$ & 107 & 28.4 \\
\hline $30-39$ & 157 & 41.6 \\
\hline $40-49$ & 63 & 16.7 \\
\hline 50 and above & 50 & 13.2 \\
\hline \multicolumn{3}{|c|}{$($ Mean $=36.2$, Std deviation= $=9.6)$} \\
\hline \multicolumn{3}{|l|}{ Gender: } \\
\hline Male & 52 & 13.8 \\
\hline Female & 325 & 86.2 \\
\hline \multicolumn{3}{|l|}{ Education: } \\
\hline High school or less & 13 & 3.4 \\
\hline Bachelors' degree & 299 & 79.3 \\
\hline Postgraduate degree & 65 & 17.2 \\
\hline \multicolumn{3}{|l|}{ Experience (years): } \\
\hline$<5$ & 161 & 42.7 \\
\hline $5-9$ & 103 & 27.3 \\
\hline $10-14$ & 76 & 20.2 \\
\hline $15-19$ & 21 & 5.6 \\
\hline 20 and above & 16 & 4.2 \\
\hline \multicolumn{3}{|c|}{$($ Mean $=7.1$, Std deviation=5.5) } \\
\hline \multicolumn{3}{|l|}{ Profession: } \\
\hline Physician & 65 & 17.2 \\
\hline Nurse & 247 & 65.5 \\
\hline Other & 65 & 17.2 \\
\hline
\end{tabular}

b. Literacy and Use of Information Technology

Table II presents the levels of IT applications' knowledge and training and frequency of IT use. The results show that about two-thirds of the respondents attended training courses in information applications, while the remaining respondents, 34.5 percent, stated that they didn't attend any training course in this field. With regards to information technology literacy, 82.8 percent of the respondents stated that they had good knowledge and skills in the use of information applications, whereas 17.2 percent had poor skills in the use of information applications. However, the results show that most respondents who had training in IT had also good IT applications skills. The Chi-squared test confirmed there were significant relationship between training and IT knowledge at 0.01 level of significance. As can be seen from the table, 62.1 percent had training in IT field had also good IT skills compared to 20.7 percent of the respondents who had no training and had good IT knowledge. These results indicated that training has positive effect on health providers' IT knowledge and skills.

Table II shows also that, the vast majority of the respondents, 86.2 percent, reported that they always use systems' applications, while 10.3 percent stated that they sometimes systems' applications. The remaining 3.4 percent of the respondents expressed that they rarely use systems' applications in KAMC. However, the results show there was significant relationship between frequency of systems' application use and IT knowledge at 0.01 level of significance. The results show that most respondents with good IT applications skills use always KAMC computerized systems.

TABLE II. RELATIONSHIPS BETWEEN RESPONDENTS' IT KNOWLEDGE WITH TRAINING AND FREQUENCY IT USE

\begin{tabular}{|c|c|c|c|c|}
\hline & $\begin{array}{r}\text { Knowl } \\
\text { appl }\end{array}$ & $\begin{array}{l}\text { ge of IT } \\
\text { tions }\end{array}$ & Total & $\begin{array}{c}\text { Chi-square } \\
\text { Test }\end{array}$ \\
\hline & Good & Poor & & \\
\hline Training: & & & & \\
\hline & 234 & 13 & 247 & \\
\hline 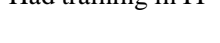 & $62.1 \%$ & $3.4 \%$ & $65.5 \%$ & \\
\hline Did not have & 78 & 52 & 130 & \\
\hline training in IT & $20.7 \%$ & $13.8 \%$ & $34.5 \%$ & \\
\hline & 312 & 65 & 377 & \\
\hline All respondents & $82.8 \%$ & $17.2 \%$ & $100 \%$ & $\begin{array}{l}\chi^{2}=75.7 \\
(\text { sig. }=0.000)\end{array}$ \\
\hline $\begin{array}{l}\text { Frequency of IT } \\
\text { use: }\end{array}$ & & & & \\
\hline Always & 286 & 39 & 325 & \\
\hline & $75.9 \%$ & $10.3 \%$ & $86.2 \%$ & \\
\hline sometimes & 13 & 26 & 39 & \\
\hline & $3.4 \%$ & $6.9 \%$ & $10.3 \%$ & \\
\hline Rarely & 13 & 0 & 13 & \\
\hline & $3.4 \%$ & $0.0 \%$ & $3.4 \%$ & \\
\hline & 312 & 65 & 377 & \\
\hline All respondents & $82.8 \%$ & $17.2 \%$ & $100 \%$ & $\begin{array}{l}\chi^{2}=72.0 \\
(\text { sig. }=0.000)\end{array}$ \\
\hline
\end{tabular}

c. Perceptions of healthcare providers towards the benefits, barriers, and motives to use information technology applications in KAMC

Table III presents the perceptions of healthcare providers towards benefits, barriers, and motives to use IT applications. The high mean scores of the respondents' responses on benefits of IT applications, ranged between 3.6 to 4.4, reveal that all the respondents perceive that the information technology applications in KAMC are valuable. Therefore, healthcare providers believe that all information technology applications are important and beneficial to both patients and KAMC

With regard to barriers to IT use, the mean scores of the respondents' responses ranged between 2.6 to 3.4. This explains that the respondents were split over the barriers to IT use in KAMC. The results of the t-test show that the following represent barriers to IT use in KAMC (items with p-values less than or equal 0.05$)$ : 
- Insufficient number of computers

- $\quad$ Time consuming

- Low system performance

- System being down frequently

The results of the t-test show that the following do not represent barriers to IT use in KAMC (items with p-values greater than 0.05 ):

- Lack of training for the hospital staff

- Lack of technical support

- Incapability of the system

- Lack of management support

As for drivers to IT use, the respondents' mean score on items measuring the motives of IT use ranged from 3.58 to 3.89 , implying the respondents agree with four motives shown in the table. Therefore, it can concluded that healthcare providers generally would be motivated to use IT applications in KAMC by provision of new applications and training, contribution in change hospital's work procedures, and provision of technical support.

d. The effect of gender, occupation, and training on respondents' perceptions towards IT benefits, barriers to using IT, and motives to using IT variables:

\section{1) Gender:}

Two-sample t-test was used to test whether there are differences in respondents' perceptions towards IT benefits, barriers to using IT, and motives to using IT variables with respect to gender. As for benefits of IT, Table IV shows that there were significant differences in respondents' perceptions on items $2,4,6,7,8,9$, and 13 with respect to gender at 0.05 significance level. The mean score of these items by gender show that the female respondents rated items "provides speed to accomplish work", "easier to find investigation results", "facilitates coordination among departments", and "improves quality of patients' care" significantly higher than did male respondents. Whereas, male respondents were more likely to agree on items "prevent loss of patients data", "helps in preparing hospital reports ", and "improves decisions making process" compared to female respondents.

TABLE III. RESPONDENTS' PERCEPTIONS TOWARDS BENEFITS, BARRIERS, AND MOTIVES TO USE INFORMATION TECHNOLOGY APPLICATIONS IN KAMC $(\mathrm{N}=377)$

\begin{tabular}{|c|c|c|c|c|}
\hline Item & 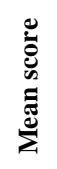 & 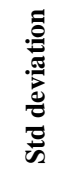 & $\begin{array}{l}\frac{\mathscr{U}}{\mathrm{E}} \\
\frac{\mathrm{E}}{\mathrm{I}}\end{array}$ & 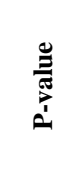 \\
\hline \multicolumn{5}{|l|}{ Benefits of IT: } \\
\hline 1. Easier to access patient records & 4.4 & 0.61 & 43.3 & 0.000 \\
\hline $\begin{array}{l}\text { 2. Easier to find investigation } \\
\text { results }\end{array}$ & 4.4 & 0.62 & 44.9 & 0.000 \\
\hline
\end{tabular}

\begin{tabular}{|c|c|c|c|c|}
\hline Item & 总 & 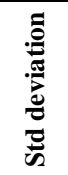 & 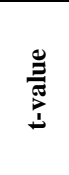 & 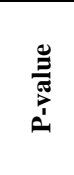 \\
\hline 3. Prevent loss of patients` data & 4.3 & 0.71 & 36.7 & 0.000 \\
\hline $\begin{array}{l}\text { 4. Helps in preparing hospital } \\
\text { reports }\end{array}$ & 4.3 & 0.81 & 30.8 & 0.000 \\
\hline 5. Helps in managing patients & 4.2 & 0.81 & 28.5 & 0.000 \\
\hline $\begin{array}{l}\text { 6. Provides speed to accomplish } \\
\text { work }\end{array}$ & 4.1 & 0.77 & 28.3 & 0.000 \\
\hline 7. Saving paper work & 4.0 & 1.01 & 19.4 & 0.000 \\
\hline $\begin{array}{l}\text { 8. Facilitates coordination } \\
\text { among departments }\end{array}$ & 4.0 & 0.99 & 18.9 & 0.000 \\
\hline $\begin{array}{l}\text { 9. Improves decisions making } \\
\text { process }\end{array}$ & 4.0 & 0.86 & 21.8 & 0.000 \\
\hline 10. Ensures patients` privacy & 4.0 & 1.00 & 19.7 & 0.000 \\
\hline 11. Reduces medical errors & 3.9 & 0.70 & 24.1 & 0.000 \\
\hline $\begin{array}{l}\text { 12. Improves quality of patients' } \\
\text { care }\end{array}$ & 3.9 & 0.91 & 19.3 & 0.000 \\
\hline 13. Decreases work load & 3.6 & 1.27 & 8.5 & 0.000 \\
\hline \multicolumn{5}{|l|}{ Barriers to IT use: } \\
\hline 1. Time consuming & 3.4 & 1.18 & 5.9 & 0.000 \\
\hline $\begin{array}{l}\text { 2. Insufficient number of } \\
\text { computers }\end{array}$ & 3.2 & 1.26 & 3.0 & 0.001 \\
\hline 3. System being down frequently & 3.1 & 1.12 & 2.5 & 0.007 \\
\hline 4. Low system performance & 3.1 & 1.08 & 1.6 & 0.053 \\
\hline $\begin{array}{l}\text { 5. Lack of training for the } \\
\text { hospital staff }\end{array}$ & 2.9 & 1.07 & -1.2 & 0.880 \\
\hline 6. Lack of technical support & 2.7 & 1.04 & -5.9 & 1.000 \\
\hline 7. Incapability of the system & 2.6 & 0.87 & -9.9 & 1.000 \\
\hline 8. Lack of management support & 2.6 & 0.98 & -7.9 & 1.000 \\
\hline $\begin{array}{l}\text { Motives to IT use: } \\
\text { 1. Provide new / durable } \\
\text { applications }\end{array}$ & 3.8 & 0.65 & 23.3 & 0.000 \\
\hline \multirow{2}{*}{$\begin{array}{l}\text { 2. Provide training to staff } \\
\text { 3. Change hospital's work } \\
\text { procedures }\end{array}$} & 3.8 & 0.79 & 20.0 & 0.000 \\
\hline & 3.6 & 0.87 & 13.1 & 0.000 \\
\hline 4. Provide technical support & 3.9 & 0.62 & 28.1 & 0.000 \\
\hline
\end{tabular}

The two-sample test's results show there were no significant differences between male and female respondents in their perceptions towards items $1,3,5,10,11$, and12 at 0.05 level of significance.

With respect to barriers to IT use, the results of two-sample t-test show that there were significant differences in perceptions of respondents on all items except for items 5 , and 6 by gender. Male respondents indicated a higher agreement with the first two barriers (insufficient number of computers and time consuming) than did female respondents. While, females were likely to agree on four barriers, low system performance, system being down frequently, incapability of the system, and lack of management support, than male respondents. Furthermore, the results show there were no significant differences in the perceptions of male and female 
respondents towards "lack of training for the hospital staff" and "lack of technical support" at 0.05 level of significance.

As for motives, the results show there were significant differences between male and female respondents in their attitudes towards the item which states "IT provides motives new / durable applications" at 0.05 level of significance. Female respondents indicated a higher agreement with the statement compared with male respondents. Whereas, the results show no other significant perceptions differences between male and female respondents on the remaining items, "provide training to staff", "change hospital's work procedures" and "provide technical support", at 0.05 level of significance. This means all health providers, regardless their gender, agreed that these three items represent motives to IT applications in KAMC

TABLE IV. RESULTS OF TWO-SAMPLE T-TEST OF IT BENEFITS, BARRIERS, AND MOTIVES WITH RESPECT TO GENDER

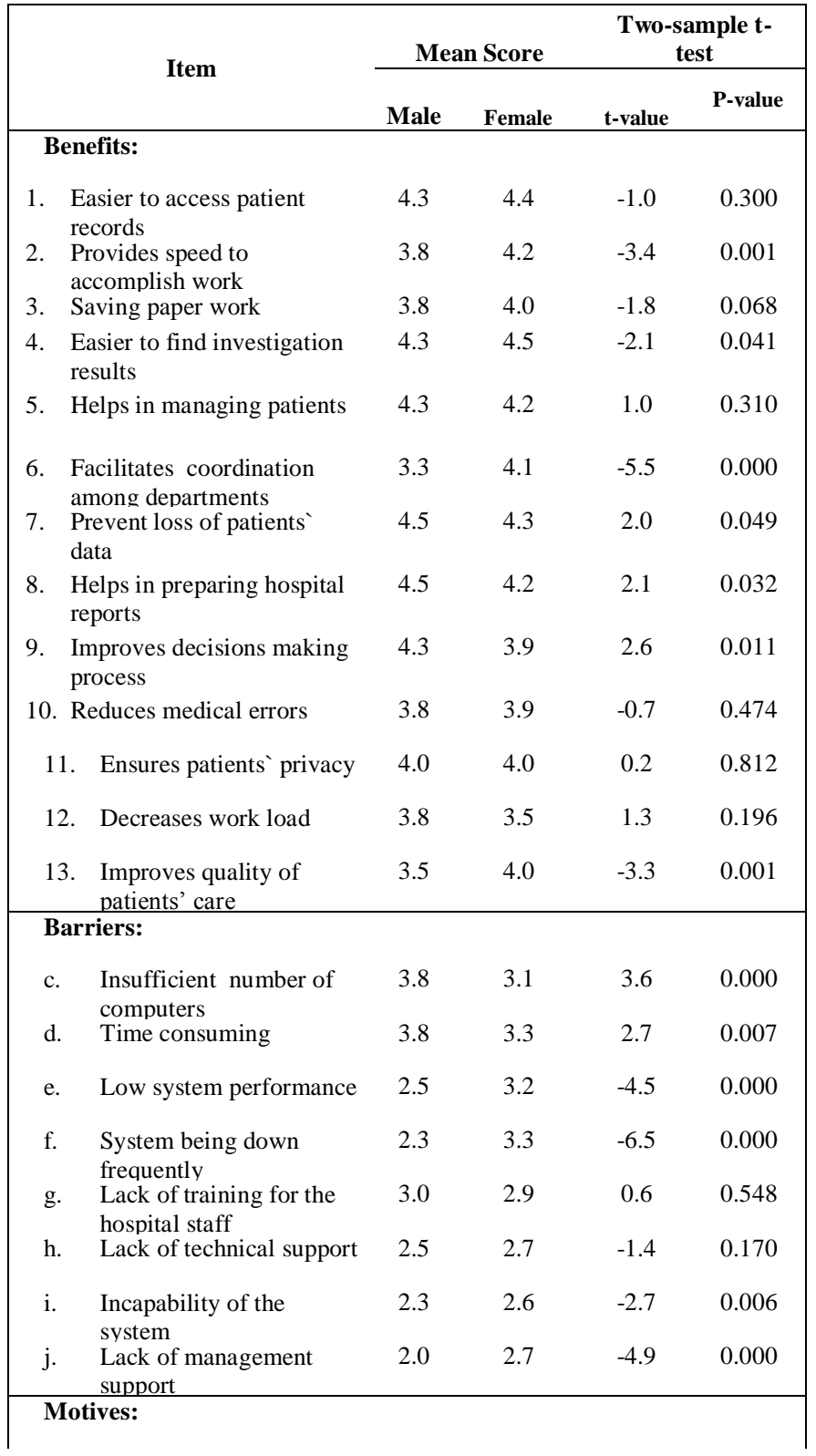

\begin{tabular}{|c|c|c|c|c|c|}
\hline 1. & $\begin{array}{l}\text { Provide new / durable } \\
\text { applications }\end{array}$ & 3.5 & 3.8 & -3.2 & 0.002 \\
\hline 2. & Provide training to staff & 3.8 & 3.8 & -0.3 & 0.800 \\
\hline 3. & $\begin{array}{l}\text { Change hospital's work } \\
\text { procedures }\end{array}$ & 3.8 & 3.6 & 1.7 & 0.096 \\
\hline 4. & $\begin{array}{l}\text { Provide technical } \\
\text { support }\end{array}$ & 4.0 & 3.9 & 1.9 & 0.063 \\
\hline
\end{tabular}

\section{2) Occupation:}

One-way Analysis of Variance (ANOVA) was used to determine whether there was a significant mean difference in the respondent's perceptions on benefits of IT applications, barriers to using IT applications, and motives to use IT applications with respect to occupation. Table $\mathrm{V}$ demonstrates the results of ANOVA test of IT benefits with occupation.

As for benefits, the results of the ANOVA tests showed that there were significant differences between physicians, nurses and other staff in their perceptions of all items measuring the benefits of IT applications at 0.05 significance level. Nurses had a higher positive perception than physicians and other staff in the following items:

- Provides speed to accomplish work.

- Easier to find investigation results.

- Helps in preparing hospital reports.

- Improves decisions making process.

- Decreases work load.

Whereas, other staff indicated higher agreement with the following statements when compared to physicians and nurse:

- Easier to access patient records

- Saving paper work

- Helps in managing patients

- Facilitates coordination among departments

- Prevent loss of patients` data

- Reduces medical errors

- Ensures patients` privacy

- Improves quality of patients' care

Interestingly, the physician's respondents indicated the lowest agreement with all statements that measure the benefits of IT applications in KAMC. These results are sensible since all these benefits affect the performance of nurses and other staff more than physicians. For example, from physician's point of view IT does not decrease their workload, which is why it was rated by them as low as 1.6 compared to 4 and 3.8 for nurses and other staff respectively.

As for barriers, the results of the ANOVA tests showed that there were significant differences between physicians, nurses and other staff in their perceptions of all items measuring barriers to use IT applications at 0.05 significance level; all pvalues were strictly less than 0.02 . Physicians indicated higher agreement with the following seven statements: 
- Insufficient number of computers

- Time consuming

- Low system performance

- System being down frequently

- Lack of training for the hospital staff

- Lack of technical support

- Incapability of the system

- Lack of management support

Whereas, the results show that the higher mean score of respondents responses to item "System being down frequently" was for other staff, followed by nurses and physicians. It is also noted that nurse respondents were less likely to agree with these stated barriers.

Table $\mathrm{V}$ presents the results of ANOVA test of motives IT applications use with occupation as the factor.

Regarding motives, the ANOVA results showed that there were significant differences between physicians, nurses and other staff in their perceptions of all items measuring motives to IT use at 0.01 significance level. Other staff respondents indicated higher agreement with the statements "Provide new/durable applications ", "Provide training to staff", and "Provide technical support" compared to physicians and nurses:

TABLE V. ONE-WAY ANALYSIS OF VARIANCE TEST OF IT BENEFITS AND OCCUPATION

\begin{tabular}{|c|c|c|c|c|c|c|}
\hline \multirow[t]{2}{*}{ Item } & \multicolumn{4}{|c|}{ Mean score } & \multicolumn{2}{|c|}{ ANOVA } \\
\hline & Physician & Nurse & Other & Total & $\mathbf{F}$ & Sig. \\
\hline \multicolumn{7}{|l|}{ Benefits: } \\
\hline $\begin{array}{l}\text { Easier to access } \\
\text { patient records }\end{array}$ & 4.2 & 4.3 & 4.6 & 4.4 & 7.3 & 0.001 \\
\hline $\begin{array}{l}\text { Provides speed } \\
\text { to accomplish } \\
\text { work }\end{array}$ & 3.6 & 4.2 & 4.2 & 4.1 & 17.3 & 0.000 \\
\hline $\begin{array}{l}\text { Saving paper } \\
\text { work }\end{array}$ & 2.6 & 4.3 & 4.4 & 4.0 & 121.5 & 0.000 \\
\hline $\begin{array}{l}\text { Easier to find } \\
\text { investigation }\end{array}$ & 4.2 & 4.5 & 4.5 & 4.4 & 4.7 & 0.010 \\
\hline $\begin{array}{l}\text { Helps in } \\
\text { managing }\end{array}$ & 4.0 & 4.2 & 4.4 & 4.2 & 4.2 & 0.015 \\
\hline $\begin{array}{l}\text { Facilitates } \\
\text { coordination }\end{array}$ & 3.0 & 4.1 & 4.2 & 4.0 & 48.1 & 0.000 \\
\hline $\begin{array}{l}\text { Prevent loss of } \\
\text { patients` data }\end{array}$ & 4.0 & 4.4 & 4.6 & 4.3 & 12.6 & 0.000 \\
\hline $\begin{array}{l}\text { Helps in } \\
\text { preparing }\end{array}$ & 4.0 & 4.4 & 4.0 & 4.3 & 10.5 & 0.000 \\
\hline $\begin{array}{l}\text { Improves } \\
\text { decisions making }\end{array}$ & 3.2 & 4.2 & 4.0 & 4.0 & 37.9 & 0.000 \\
\hline $\begin{array}{l}\text { Reduces medical } \\
\text { errors }\end{array}$ & 3.6 & 3.9 & 4.0 & 3.9 & 5.1 & 0.007 \\
\hline $\begin{array}{l}\text { Ensures patients` } \\
\text { privacy }\end{array}$ & 3.6 & 4.0 & 4.4 & 4.0 & 10.2 & 0.000 \\
\hline $\begin{array}{l}\text { Decreases work } \\
\text { load }\end{array}$ & 1.6 & 4.0 & 3.8 & 3.6 & 178.3 & 0.000 \\
\hline
\end{tabular}

\begin{tabular}{|c|c|c|c|c|c|c|}
\hline \multirow[t]{2}{*}{ Item } & \multicolumn{4}{|c|}{ Mean score } & \multicolumn{2}{|c|}{ ANOVA } \\
\hline & Physician & Nurse & Other & Total & $\mathbf{F}$ & Sig. \\
\hline $\begin{array}{l}\text { Improves } \\
\text { quality of }\end{array}$ & 3.0 & 4.0 & 4.6 & 3.9 & 72.4 & 0.000 \\
\hline \multicolumn{7}{|l|}{ Barriers: } \\
\hline $\begin{array}{l}\text { Insufficient } \\
\text { number of } \\
\text { computers }\end{array}$ & 3.6 & 3.1 & 3.2 & 3.2 & 4.3 & 0.015 \\
\hline $\begin{array}{l}\text { Time } \\
\text { consuming }\end{array}$ & 4.4 & 3.1 & 3.4 & 3.4 & 39.7 & 0.000 \\
\hline $\begin{array}{l}\text { Low system } \\
\text { performance }\end{array}$ & 3.8 & 2.9 & 3.2 & 3.1 & 21.6 & 0.000 \\
\hline $\begin{array}{l}\text { performance } \\
\text { System being } \\
\text { down } \\
\text { frequently }\end{array}$ & 2.8 & 3.1 & 3.8 & 3.1 & 17.5 & 0.000 \\
\hline $\begin{array}{l}\text { Lack of } \\
\text { training for } \\
\text { the hospital }\end{array}$ & 3.4 & 2.9 & 2.6 & 2.9 & 10.6 & 0.000 \\
\hline $\begin{array}{l}\text { Lack of } \\
\text { technical } \\
\text { support }\end{array}$ & 3.4 & 2.5 & 2.6 & 2.7 & 23.0 & 0.000 \\
\hline $\begin{array}{l}\text { Incapability of } \\
\text { the system }\end{array}$ & 3.0 & 2.4 & 2.6 & 2.6 & 12.6 & 0.000 \\
\hline $\begin{array}{l}\text { Lack of } \\
\text { management } \\
\text { support }\end{array}$ & 3.0 & 2.6 & 2.4 & 2.6 & 6.8 & 0.001 \\
\hline \multicolumn{7}{|l|}{ Motives: } \\
\hline $\begin{array}{l}\text { Provide } \\
\text { new/durable } \\
\text { applications }\end{array}$ & 3.0 & 3.9 & 4.0 & 3.8 & 81.2 & 0.000 \\
\hline $\begin{array}{l}\text { Provide } \\
\text { training to } \\
\text { staff }\end{array}$ & 2.8 & 4.0 & 4.2 & 3.8 & 109.2 & 0.000 \\
\hline $\begin{array}{l}\text { Change } \\
\text { hospital's } \\
\text { work }\end{array}$ & 3.2 & 3.7 & 3.4 & 3.6 & 13.6 & 0.000 \\
\hline $\begin{array}{l}\text { Provide } \\
\text { technical } \\
\text { support }\end{array}$ & 3.4 & 3.9 & 4.2 & 3.9 & 33.3 & 0.000 \\
\hline
\end{tabular}

\section{3) Training:}

A two-sample t-test was performed to test whether there were differences in respondents' perceptions towards IT benefits, barriers and motives to using IT with respect to training (Table VI). As for IT benefits, the results show that there were significant differences ( $\mathrm{p}$-value $<0.05)$ in perceptions of respondents who had training in IT and those who had no training on all items except items "Ensures patients' privacy" and "Improves quality of patients' care". It is worth noting that the mean scores of the respondents who had training on these items were higher than the mean scores of the respondents who did not attend training in IT field. This shows that the staff who attended training courses in IT perceive the benefits of IT more than those who did not attend training courses in this field. As shown in the table, the two-sample test's results show that there were no significant differences in the perceptions of staff who had training and those did not attend training on items: "Ensures patients' privacy" and "Improves quality of patients' care"

As for barriers, the results show there were significant differences between respondents who attended training in IT and those who did not attend training in their perceptions 
towards barriers to using health information applications in KAMC in the following items:

- $\quad$ Time consuming

- Low system performance

- Lack of training for the hospital staff

- $\quad$ Lack of technical support

The mean scores of the respondents who did not attend training on IT on these items were higher than the mean scores of the respondents who had training except for the item "low system performance". This indicates that the staff who attended training courses in IT perceive less obstacles to IT use in KAMC compared to staff who had no training in IT. Conversely, the respondents who had training in IT perceive that the system performance was low more than those who had no training in IT. Moreover, the results show there were no significant differences between respondents who had training in IT and those who had no training in their perceptions towards barriers to using health information applications in $\mathrm{KAMC}$ in the following items:

- Insufficient number of computers

- $\quad$ System being down frequently

- Incapability of the system

- $\quad$ Lack of management support

With regards to drivers of IT use, the results show there were significant differences between respondents who attended training in IT and those who did not attend training in their perceptions towards two items; "IT provides new/durable applications" and "IT provides technical support at 0.05 level of significance. The mean scores of the respondents who did not attend training on IT on these items were higher than the mean scores of the respondents who had training except for the item "Provide new / durable applications". This reveal s that the staff who attended training courses in IT perceive less motivation to IT use in KAMC compared to those who had no training in IT. On the contrary, the respondents who had training in IT perceive that IT provides technical support more than those who had no training in IT. Furthermore, there were no significant differences between respondents who had training in IT and those who had no training in their perceptions towards two items; "IT provides training to staff" and "IT changes hospital's work procedures".

TABLE VI. RESULTS OF TWO-SAMPLE T-TEST OF IT BENEFITS, BARRIERS, AND MOTIVES WITH RESPECT TO ATTENDANCE OF TRAINING IN IT

\begin{tabular}{|lcccc|}
\hline \multirow{2}{*}{ Items } & \multicolumn{2}{c}{ Mean Score } & \multicolumn{2}{c|}{ Two-sample t-test } \\
\cline { 2 - 5 } & Attended & $\begin{array}{c}\text { Not } \\
\text { attended }\end{array}$ & t-value & P-value \\
\hline Benefits: & & & & \\
$\begin{array}{l}\text { Easier to access patient } \\
\text { records }\end{array}$ & 4.5 & 4.0 & 8.0 & 0.000 \\
$\begin{array}{l}\text { Provides speed to accomplish } \\
\text { work }\end{array}$ & 4.2 & 3.9 & 3.8 & 0.000 \\
Saving paper work & 4.2 & 3.7 & 3.9 & 0.000 \\
\hline
\end{tabular}

\begin{tabular}{|c|c|c|c|c|}
\hline \multirow{2}{*}{ Items } & \multicolumn{2}{|c|}{ Mean Score } & \multicolumn{2}{|c|}{ Two-sample t-test } \\
\hline & Attended & $\begin{array}{c}\text { Not } \\
\text { attended }\end{array}$ & t-value & P-value \\
\hline $\begin{array}{l}\text { Easier to find investigation } \\
\text { results }\end{array}$ & 4.5 & 4.3 & 3.2 & 0.001 \\
\hline Helps in managing patients & 4.3 & 3.9 & 4.5 & 0.000 \\
\hline $\begin{array}{l}\text { Facilitates coordination } \\
\text { among departments }\end{array}$ & 4.1 & 3.8 & 2.4 & 0.016 \\
\hline Prevent loss of patients` data & 4.4 & 4.2 & 3.4 & 0.001 \\
\hline $\begin{array}{l}\text { Helps in preparing hospital } \\
\text { reports }\end{array}$ & 4.4 & 4.1 & 2.7 & 0.006 \\
\hline $\begin{array}{l}\text { Improves decisions making } \\
\text { process }\end{array}$ & 4.2 & 3.6 & 6.2 & 0.000 \\
\hline Reduces medical errors & 4.0 & 3.6 & 5.9 & 0.000 \\
\hline Ensures patients` privacy & 4.0 & 4.0 & -0.3 & 0.747 \\
\hline Decreases work load & 3.7 & 3.3 & 3.1 & 0.002 \\
\hline $\begin{array}{l}\text { Improves quality of patients' } \\
\text { care }\end{array}$ & 4.0 & 3.8 & 1.5 & 0.134 \\
\hline \multicolumn{5}{|l|}{ Barriers: } \\
\hline $\begin{array}{l}\text { Insufficient number of } \\
\text { computers }\end{array}$ & 3.2 & 3.2 & 0.0 & 0.965 \\
\hline Time consuming & 3.2 & 3.7 & -4.2 & 0.000 \\
\hline Low system performance & 3.2 & 2.9 & 2.6 & 0.010 \\
\hline $\begin{array}{l}\text { System being down } \\
\text { frequently }\end{array}$ & 3.1 & 3.2 & -0.9 & 0.365 \\
\hline $\begin{array}{l}\text { Lack of training for the } \\
\text { hospital staff }\end{array}$ & 2.8 & 3.2 & -3.6 & 0.000 \\
\hline Lack of technical support & 2.5 & 3.0 & -4.6 & 0.000 \\
\hline Incapability of the system & 2.6 & 2.5 & 0.8 & 0.451 \\
\hline Lack of management support & 2.6 & 2.7 & -1.3 & 0.197 \\
\hline \multicolumn{5}{|l|}{ Motives: } \\
\hline $\begin{array}{l}\text { Provide new / durable } \\
\text { applications }\end{array}$ & 3.7 & 3.9 & -2.9 & 0.004 \\
\hline Provide training to staff & 3.9 & 3.7 & 1.9 & 0.057 \\
\hline $\begin{array}{l}\text { Change hospital's work } \\
\text { procedures }\end{array}$ & 3.6 & 3.6 & -0.3 & 0.789 \\
\hline Provide technical support & 4.0 & 3.7 & 3.7 & 0.000 \\
\hline
\end{tabular}

\section{DISCUSSION}

The results show that the majority of healthcare providers use KAMC health information systems when the survey was conducted. This result somewhat conflicts with Ananzy [19] who found about 26 percent of healthcare providers use electronic health records in six hospitals in Riyadh. Despite the high HIT use, KAMC healthcare providers with good IT skills used KAMC computerized systems more than those with poor skills. This finding is consistent with that of Alam and Noor $[27,28]$ who found significant effects of IT skills on adoption of ICT.

The high mean scores of the respondents' responses on benefits of HIT applications reveal that healthcare providers perceive that the information technology applications in KAMC are valuable and beneficial to both patients and 
KAMC. This is consistent with findings of many researches carried in USA which found that the healthcare providers perceive the benefits of HIT in improving healthcare $[29,30]$.With regard to barriers, the healthcare providers were split over the barriers to HIT use in KAMC. The healthcare providers agreed that insufficient number of computers, time consuming, low system performance, the system being down frequently as barriers to HIT use in KAMC. Whereas, they didn't perceive that lack of training for the hospital staff, lack of technical support, incapability of the system, and lack of management support were barriers to HIT use. These results are somewhat consistent with Houser and Johnson [29]. As for drivers, the results showed that healthcare providers generally would be motivated to use IT applications in KAMC by provision of new applications and training, contribution in change hospital's work procedures, and provision of technical support.

The results showed the perceptions of healthcare providers on benefits, barriers and motives were influenced by gender. However, the gender effect on perceptions of healthcare providers is not consistent, as some items of the three dimensions (benefits, barriers, and motives) were higher by males and others were rated higher by females. However, there were no significant differences in perceptions of some items between male and female health providers. These results are to some extent consistent with other research findings [31,32].

With respect to the effect occupation, the results show that there were significant differences between physicians, nurses and other staff in their perceptions towards all items measuring benefits, barriers, and motives. However, the effect of occupation is also inconsistent; as some healthcare providers had a higher positive perceptions than others. These results conform with those of other research findings [33].

As regards the effect of training, the results show that healthcare providers who attended training courses in IT perceive the benefits of HIT more than those who did not attend any training courses in this field. Similarly, the results indicate that healthcare providers who attended training courses in IT perceive less barriers to HIT use in KAMC compared to those who had no training in IT. As for drivers of IT use, the results show that the effect of training on motives to HIT use were inconsistent as there were significant differences between healthcare providers who attended training in IT and those who did not attend training in their perceptions towards some items. These results are consistent with previous research findings which acknowledged the positive impact of training on IT adoption [32,34].

The major research limitation of this study was the use of convenience sample for data collection which might not represented the target population accurately. Despite this limitation and due to the lack of research in this area, the study provides important information on the perceptions of healthcare providers towards benefits, barriers and drivers of health information technology in KAMC.

\section{CONCLUSION, ReCOMMENDATIONS AND Future SCOPE}

The purpose of this study was to assess the perceptions of healthcare providers towards health information technology applications in King Abdul-Aziz Medical City in terms of benefits, barriers, and motives to use these applications. This study also contributes in investigating the effects of gender, occupation, and training on the perceptions of the healthcare providers towards the health information applications.

Despite the perceived benefits and motives of health information technology use, there were many barriers identified by healthcare providers. The barriers include insufficient number of computers, frequent system down, and that using computerized systems is time consuming. Furthermore, there were significant differences in the perceptions of healthcare providers towards benefits, barriers, and motives to health information technology with respect gender, occupation, and training. Based on these results, the study recommends that KAMC to provide easy access to health information applications, continuous training to all healthcare providers on health information technology, technical support services and change hospital's work procedures. Further, the study also recommends that KAMC administration to engage healthcare providers in planning and promotion of health information applications.

As a future scope, more research on the adoption of health information technology applications can be carried out. The scope can also be widened by considering the effect of additional demographic and organizational variables on the adoption HIT. Moreover, similar research can be carried in other KAMC braches to trace geographic variations in HIT adoption.

\section{REFERENCES}

[1] Kaye R, Kokia E, Shalev V, darD I, Chinitz D, "Barriers and success factors in health information technology: A practitioner's perspective", Journal of Management \& Marketing in Healthcare. 2010; 3 (2): 163-175.

[2] Jones, TM. National Infrastructure for eHealth: Considerations for Decision Support. Studies in. Health Technology and Informatics, 2004; 100: 28-34

[3] Castells, M., Lupiáñez, F., Saigí, F. and Sánchez, J. E-Health and Society: An Empirical Study of Catalonia - Summary of the Final Research Report, Catalan Internet Project, UOC and Generalitat de Catalunya, Barcelona. 2007

[4] Hersh WR. Medical Informatics, "Improving Healthcare through Information". Journal of the American Medical Association. 2002; 288(16):1955-1958.

[5] Burton LC, Anderson GF, Kues IW. "Using Health Records to Help Coordinate Care". The Milbank Quarterly.2004; 82(3):457-481.

[6] Chaudhry B, Wang J, Wu S, Maglione M, Mojica W, Roth E, Morton S, Shekelle P. Systematic review: "Impact of health information technology on quality, efficiency, and costs of medical care", Annals of Internal Medicine. 2006; 144 (10):742-752.

[7] McCullough J, Casey M, Moscovice I, Prasad S. "The Effect of Health Information Technology on Quality in US Hospitals". Health Affairs. 2010; 29 (4):647-654.

[8] Hillestad R, Bigelow J, Bower Ay, Girosi F, Meili R, Scoville R and Taylor R. Can Electronic Medical Record Systems Transform Health Care? Potential Health Benefits, Savings, And Costs. Health Affairs, 2005;24(5):1103-1117.

[9] Institute of Medicine. To err is human: Building a safer health system. ed. L. Kohn, J. Corrigan, and M. Donaldson. Washington, DC: National Academy Press. 2000. 
[10] Johnson KB, Ravich WJ, Cowan JA Jr. "Brainstorming about nextgeneration computer-based documentation". International Journal of Medical Information. 2004; 73(9-10):665-674.

[11] Anderson, JG., Computer-based ambulatory information systems: recent development, 2000

[12] Shekelle PG, Morton SC, Keeler EB. "Costs and Benefits of Health Information Technology". Evidence Report/Technology Assessment No. 132. AHRQ Publication No.06-E006. Rockville, MD: Agency for Healthcare Research and Quality. April 2006.

[13] Agarwal R, and Prasad J. "The Antecedents and Consequents of User Perceptions in Information Technology Adoption". Decision Support Systems. 1998; 22:15-29.

[14] Venkatesh V, Morris M, Davis GB, Davis FD. "User Acceptance of Information Technology: Toward a Unified View". MIS Quarterly. 2003; 27(3):425-78.

[15] Morton ME. "Use and Acceptance of an Electronic Health Record: Factors Affecting Physician Attitudes". Unpublished dissertation, Drexel University. 2008.

[16] Kim KK, Michelman J. "An examination of factors for the strategic use of information systems in the health care industry". MIS Qtly. 1990;14(2): 201-215.

[17] Chau P, Hu P. "Examining a model of information technology acceptance by individual professionals: An exploratory study". Journal of Management Information Systems. 2001; 18:191-229.

[18] Devaraj S, Kohli R. "Performance Impacts of Information Technology: Is Actual Usage the Missing Link?" Management Science. 2003;49(3):273-289.

[19] Kohli R, Kettinger WJ. "Informating the Clan: Controlling Physician Costs and Outcomes". MIS Quarterly. 2004; 28(3): 363-394.

[20] Ministry of Economy and Planning. Ninth development plan; 20102014. Ministry of Economy and Planning, Kingdom of Saudi Arabia. 2010 .

[21] Alanazy, S. "Factors Associated With Implementation of Electronic Health Records in Saudi Arabia". Unpublished $\mathrm{PhD}$ dissertation submitted to the University of Medicine and Dentistry of New Jersey.2006.

[22] Harrison JP, Daly MA. "Leveraging Health Information Technology to Improve Patient Safety". Public Administration \& Management. 2009; 13(3):218-237.
[23] De Vellis RE Scale development: Theory and application (2nd edn) Thousand Oaks, California: Sage. 2003.

[24] Morgan GA, Gliner JA, Harmon RJ. Understanding and evaluating research in applied clinical settings. Publisher: Lawrence Erlbaum Associates; 2006.

[25] Roberts-Lombard M. Marketing Research - A South African Perspective. (3rd ed.). Cape Town: Oxford University Press. 2002.

[26] Ministry of Health. Health Statistical Year Book. Ministry of Health. Kingdom of Saudi Arabia. 2009.

27] Alam, SS, Noor, MKM. "ICT Adoption in Small and Medium Enterprises: an Empirical Evidence of Service Sectors in Malaysia". International Journal of Business and Management. 2009; 4(2):112125 .

[28] Hashim J. Information Communication Technology (ICT) Adoption Among SME Owners in Malaysia. International Journal of Business and Information; 2007; 2(2):221-240.

[29] Houser SH, Johnson L. "Perceptions Regarding Electronic Health Record Implementation among Health Information Management Professionals in Alabama: A Statewide Survey and Analysis". Perspectives in Health Information Management. 2008; 5; 6.

[30] Thakkar M, Davis DC. Risks, Barriers, and Benefits of EHR Systems: "A Comparative Study Based on Size of Hospital. Perspectives in Health Information Management". 2006; 3(5):1-10.

[31] MacGregor R, Hyland P, Harvie C. (The Effect of Gender on Perceived Benefits of and Drivers for ICT Adoption in Australian Medical Practices. International Journal of E-Politics. 2011; 2(1):6885.

[32] Yu P, Li H, Gagnon M. "Health IT acceptance factors in long-term care facilities: A cross-sectional survey". International Journal of Medical Informatics. 2009; 78:219-229.

[33] McDonald CJ, Overhage JM, Tierney WM, Dexter PR, Martin DK, Suico JG, et al. The Regenstrief Medical Record System: a quarter century experience. International Journal of Medical Informatics 1999;54:225-53.

[34] Shachak A Fine S. The effect of training on biologists acceptance of bioinformatics tools: A field experiment. Journal of American Society for Information Science. 2008;59(5):719-730. 